\title{
Respon Dua Varietas Tanaman Kentang (Solanum tuerosum L.) Terhadap Aplikasi Pupuk Majemuk NPK
}

\author{
Dian Nitami Quraisyin ${ }^{1^{\star}}$, Sugiarto ${ }^{1}$, Nurhidayati ${ }^{1}$ \\ ${ }^{1}$ Departemen Agroteknologi, Fakultas Pertanian, Universitas Islam Malang, \\ Jalan MT. Haryono, No. 193, Malang 65144, Jawa Timur, Indonesia \\ Email korespondensi: diannitami2496@yahoo.com
}

\begin{abstract}
Abstrak
Permintaan kentang dari waktu ke waktu semakin meningkat. Oleh karena itu perlu upaya peningkatan produktivitas kentang melalui teknik budidaya yang tepat khususnya pada varietas yang baru. Penelitian ini bertujuan untuk mengetahui pengaruh pemberian dosis pupuk NPK $(16: 16: 16)$ terhadap pertumbuhan dan hasil dua varietas tanaman kentang di dataran tinggi. Rancangan yang digunakan adalah Rancangan Acak Kelompok (RAK) Faktorial dengan menggunakan 2 faktor. Faktor pertama adalah pemberian dosis pupuk NPK dengan 3 level yaitu $\mathrm{PO}=$ tanpa pemberian pupuk, $\mathrm{P} 1=400 \mathrm{~kg}$ pupuk NPK ha-1 dan P2 $=800 \mathrm{~kg}$ pupuk NPK ha-1. Faktor kedua yaitu macam varietas dengan 2 level, $V 1=$ Granolla $L$ dan V2 $=$ Granolla Arjuno). Dari dua faktor tersebut diperoleh 6 kombinasi perlakuan, Tiap-tiap perlakuan diulang 3 kali. Ada dua variabel pengamatan yaitu variabel tumbuh (tinggi tanaman, jumlah batang, jumlah daun dan diameter batang) dan variabel hasil (jumlah umbi pertanaman, jumlah umbi per-petak, bobot umbi per-tanaman, bobot umbi per-petak dan bobot umbi per-hektar). Data yang diperoleh dianalisa ragam pada taraf $5 \%$ dilanjutkan dengan_uji BNT 5\%. Hasil penelitian menunjukkan bahwa pertumbuhan tanaman terbaik adalah varietas Granolla Arjuno dengan dosis pupuk NPK 400 kg ha-1 (P1V2). Sedangkan perlakuan yang memberikan hasil tertinggi adalah varietas Granolla Arjuno dengan dosis pupuk N-P-K $400 \mathrm{~kg}$ ha-1 (P1V2).
\end{abstract}

Kata kunci: Kentang Varietas Granolla L, Kentang Varietas Granolla Arjuno, Pupuk NPK (16:16:16)

\begin{abstract}
Demand for potatoes from time to time is increasing. Therefore it is necessary to increase the productivity of potatoes through appropriate cultivation techniques especially in new potato varieties. This study aimed to determine the effect of NPK (16:16:16) fertilizer dosage on the growth and yield of two potato varieties in the highlands. The design used was factorial Randomized Block Design (RAK) using 2 factors. The first factor was the aplication of NPK fertilizer with 3 levels, namely P0 = without fertilizer, P1 = $400 \mathrm{~kg}$ fertilizer NPK ha-1 and P2 $=800 \mathrm{~kg}$ NPK fertilizer ha-1. The second factor was the type of variety with 2 levels, V1 = Granola $L$ and V2 = Granolla Arjuno. There were two observed variables which were growth variables (plant height, number of stems, number of leaves and stem diameter) and yield variables (number of tubers, weight of , tuber per plot and per hectare). The data collected was analyzed based on F Test at the level of 5\% and LSD test 5\%. The results showed that the best plant growth was Granolla Arjuno variety with a dose of NPK fertilizer $400 \mathrm{~kg}$ ha-1 (P1V2). While the treatment that gave the highest results is Granolla Arjuno variety with a dose of N-P-K fertilizer $400 \mathrm{~kg}$ ha-1 (P1V2).
\end{abstract}

Keywords: Potato Granolla L varieties, Potato Granolla Arjuno varieties, NPK fertilizer 


\section{Pendahuluan}

Kentang merupakan tanaman penghasil karbohidrat yang sangat digemari oleh masyarakat yang dapat dikonsumsi langsung atau dalam bentuk olahan. Produksi kentang di Indonesia dari tahun 2017 ke 2018 meningkat yaitu 1.164 .738 ton ke 1.284.760 ton (Kementerian Pertanian Republik Indonesia, 2019). Luas panen kentang menurun dari 2017 ke 2018 yaitu 75.611 hektar ke 68.683 hektar (Kementerian Pertanian Republik Indonesia, 2019). Oleh karena itu, diperlukan sistem budidaya melalui pemupukan dan varietas unggul agar produksi terus meningkat pada luasan panen yang menurun.

Di antara beberapa jenis tanaman sayuran yang responsif terhadap pemupukan ialah kentang. Pupuk anorganik majemuk cukup mengandung hara dengan persentase kandungan unsur hara makro yang berimbang yaitu NPK Mutiara 16:16:16. Pupuk ini berbentuk padat mempunyai sifat lambat larut sehingga diharapkan dapat mengurangi kehilangan hara melalui pencucian, penguapan, dan pengikatan menjadi senyawa yang tidak tersedia bagi tanaman. Pupuk majemuk memenuhi kebutuhan hara $N, P, K$, $\mathrm{Mg}$, dan $\mathrm{Ca}$ bagi tanaman, warnanya kebiru-biruan dengan butiran mengkilap seperti mutiara.

Sutrisna dan Surdianto (2014) mengemukakan bahwa takaran pupuk NPK yang tepat pada tanaman kentang, baik dalam bentuk pupuk tunggal maupun majemuk mutlak diperlukan. Namun saat ini petani cenderung memilih pupuk NPK majemuk daripada pupuk tunggal, karena lebih praktis pada saat aplikasi di lapangan. Salah satu teknik budidaya yang perlu mendapatkan perhatian pada budidaya kentang adalah pemupukan. Hasil penelitian lainnya menunjukkan bahwa perlakuan pemupukan NPK berimbang berpengaruh terhadap jumlah buah maupun bobot buah per-tanaman pada tanaman kentang (Gunadi, 2009). Pupuk NPK mengandung tiga unsur hara esensial yang dibutuhkan oleh tanaman dalam jumlah banyak. Ketiga unsur hara tersebut memiliki peran masing-masing dalam menunjang pertumbuhan tanaman.

Penelitian ini bertujuan untuk mengetahui pengaruh pemberian dosis pupuk NPK (16:16:16) terhadap pertumbuhan dan hasil dua varietas tanaman kentang di dataran tinggi. Penelitian ini dapat memberikan manfaat kepada petani terkait dengan dosis pupuk anorganik yang bisa diaplikasikan sehingga mendapatkan pertumbuhan terbesar serta hasil tanaman kentang yang tinggi. 


\section{Bahan dan Metode}

Penelitian ini merupakan percobaan lapang yang dilaksanakan di Desa Sumber Brantas, Kecamatan Bumi Aji, Kota Batu Jawa Timur dengan ketinggian 1600 m diatas permukaan laut, dengan suhu rata-rata pada siang hari $21-24^{\circ} \mathrm{C}$ sedangkan suhu pada malam hari berkisar antara $12-15^{\circ} \mathrm{C}$. Penelitian ini dilaksanakan pada tanggal 30 September 2018 sampai dengan 30 Maret 2019. Rancangan yang digunakan adalah Rancangan Acak Kelompok (RAK) Faktorial dengan menggunakan 2 faktor. Faktor pertama pengaruh pemberian dosis pupuk NPK dengan 3 level yaitu $\mathrm{PO}=$ tanpa pemberian pupuk, $\mathrm{P} 1=400 \mathrm{~kg}$ pupuk NPK ha-1 dan P2 $=800 \mathrm{~kg}$ pupuk NPK ha-1. Faktor kedua yaitu macam varietas dengan 2 level, V1 = Granolla L dan V2 = Granolla Arjuno.

Bibit kentang yang digunakan dalam penelitian iniberasal dari varietas Granolla $\mathrm{L}$ dan Granolla Arjuno yang sudah bertunas $\pm 1 \mathrm{~cm}$ dengan bibit yang masih bagus dan besarnya seragam. Lahan yang digunakan digaru sedalam $5 \mathrm{~cm}$ lalu membuat guludan sebanyak 18 dengan tinggi guludan $\pm 7-10 \mathrm{~cm}$, lebar guludan $60 \mathrm{~cm}$ dan panjang guludan 4,8 dengan lebar arit $25 \mathrm{~cm}$. Bibit kentang varietas Granolla $L$ dan Granolla Arjuno ditanam secara langsung di lapang. Aplikasi pupuk NPK dilakukan 2 kali. Aplikasi pertama dilakukan 3 MST dengan $1 / 2$ dosis, aplikasi kedua dilakukan 2 minggu setelah aplikasi pertama. Pemeliharaan yang dilakukan meliputi penyiraman dengan menggunakaan sprinkle, penyiangan dan pengendalian hama dan penyakit. Pengendalian hama dan penyakit dilakukan ketika ada gejala-gejala yang ditimbulkan oleh OPT, untuk mengantisipasi terjadinya peningkatan serangan OPT dilakukan pengendalian secara intensif menggunakan pestisida. Pestisida yang digunakan adalah Nurelle D dan Asoka.

Ada dua variabel pengamatan yang dilakukan yaitu variabel tumbuh (tinggi tanaman, jumlah batang, jumlah daun dan diameter batang) dan variabel hasil (jumlah umbi per-tanaman, jumlah umbi per-petak, bobot umbi per-tanaman, bobot umbi perpetak dan bobot umbi per-hektar). Pengamatan variabel tumbuh dilakukan setiap 7 hari sekali. Data yang dikumpulkan dianalisis berdasarkan Uji $\mathrm{F}$ pada taraf $5 \%$ jika terdapat pengaruh nyata maka dilanjut dengan uji BNT 5\%. 


\section{Hasil dan Pembahasan}

\section{Pengaruh Pemberian Dosis Pupuk N-P-K terhadap Pertumbuhan Dua Varietas Tanaman Kentang (Solanum tuberosum L.)}

Hasil analisis ragam menunjukkan bahwa pemberian NPK memberikan pengaruh yang nyata terhadap variabel pertumbuhan tinggi tanaman, jumlah daun dan diameter batang pada umur 70 HST, dan pada umur 70 HST untuk jumlah batang berpengaruh nyata (Tabel 1).

Tabel 1 menunjukkan bahwa secara umum rata-rata perlakuan yang memberikan pertumbuhan tertinggi adalah P1V2 (400 kg pupuk NPK mutiara ha ${ }^{-1}$ dengan varietas Granolla Arjuno) dengan tinggi tanaman $50,83 \mathrm{~cm}$, yaitu jumlah batang 2,56 dan jumlah daun 115,44, jumlah batang 2,56, jumlah daun 115,44 dan diameter batang $1,78 \mathrm{~cm}$, sedangkan untuk varietas Granolla $\mathrm{L}$, dosis pemupukan NPK tidak memberikan perbedaan yang nyata. Namun ada kecendrungan dosis NPK $800 \mathrm{~kg} \mathrm{ha}^{-1}$ memberikan pertumbuan yang lebih baik dibandingkan dengan dosis NPK $400 \mathrm{~kg} \mathrm{ha}^{-1}$. Perbandingan rata-rata tinggi tanaman, jumlah daun, jumlah batang dan diameter batang pada dua varietas kentang yang diujikan disajikan pada gambar 1 .

Tabel 1. Rata-rata parameter tumbuh dua varietas kentang akibat perlakuan pemberian pupuk NPK $(16: 16: 16)$

\begin{tabular}{ccccc}
\hline \multirow{2}{*}{ Perlakuan } & \multicolumn{4}{c}{ Parameter Tumbuh } \\
\cline { 2 - 5 } & $\begin{array}{c}\text { Tinggi Tanaman }(\mathrm{cm}) \\
\text { Umur 70 HST }\end{array}$ & $\begin{array}{c}\text { Jumlah Batang } \\
\text { Umur 70 HST }\end{array}$ & $\begin{array}{c}\text { Jumlah Daun } \\
\text { Umur 70 HST }\end{array}$ & $\begin{array}{c}\text { Diameter Batang } \\
\text { (cm) } \\
\text { Umur 70 HST }\end{array}$ \\
\hline POV1 & $25,90 \mathrm{a}$ & $1,00 \mathrm{a}$ & $36,11 \mathrm{a}$ & $1,17 \mathrm{a}$ \\
P1V1 & $25,60 \mathrm{a}$ & $1,00 \mathrm{a}$ & $29,78 \mathrm{a}$ & $0,86 \mathrm{a}$ \\
P2V1 & $33,17 \mathrm{ab}$ & $1,22 \mathrm{ab}$ & $43,33 \mathrm{a}$ & $1,18 \mathrm{a}$ \\
P0V2 & $44,62 \mathrm{~cd}$ & $2,11 \mathrm{ab}$ & $55,56 \mathrm{a}$ & $1,52 \mathrm{~b}$ \\
P1V2 & $50,83 \mathrm{~d}$ & $2,56 \mathrm{c}$ & $115,44 \mathrm{~b}$ & $1,78 \mathrm{~b}$ \\
P2V2 & $41,89 \mathrm{bc}$ & $2,00 \mathrm{~b}$ & $56,78 \mathrm{a}$ & $1,55 \mathrm{~b}$ \\
\hline BNT 5\% & $\mathbf{8 , 8 5}$ & $\mathbf{1 , 1}$ & $\mathbf{4 3 , 2 4}$ & $\mathbf{0 , 3 4}$ \\
\hline
\end{tabular}

Keterangan: Angka yang didampingi dengan huruf yang sama pada kolom yang sama menunjukkan tidak berbeda nyata pada uji BNT 5\%, HST : Hari Setelah Tanam

Gambar 1 menunjukkan perbedaan pertumbuhan dua varietas kentang pada parameter tumbuh tinggi tanaman, jumlah daun, jumlah batang dan diameter batang, dimana varietas kentang Granolla Arjuno memberikan pertumbuhan yang lebih besar daripada varietas Granolla $L$ yaitu dengan tinggi tanaman 47,97, jumlah daun 75,93, jumlah batang 2,94 dan diameter batang 1,69. Pemberian pupuk NPK memberikan pengaruh yang nyata terhadap hasil tanaman kentang. Pertumbuhan tanaman pada dasarnya merupakan hasil penambahan ukuran organ-organ tanaman akibat 
pertambahan jaringan sel atau pembesaran jaringan sel (Qomariyah, 2018). Menurut Nurtika (2008), penambahan unsur-unsur hara yang diberikan melalui pupuk buatan adalah sangat penting untuk pertumbuhan. Pertumbuhan adalah proses dalam kehidupan tanaman yang mengakibatkan pertambahan ukuran tanaman menjadi semakin besar.
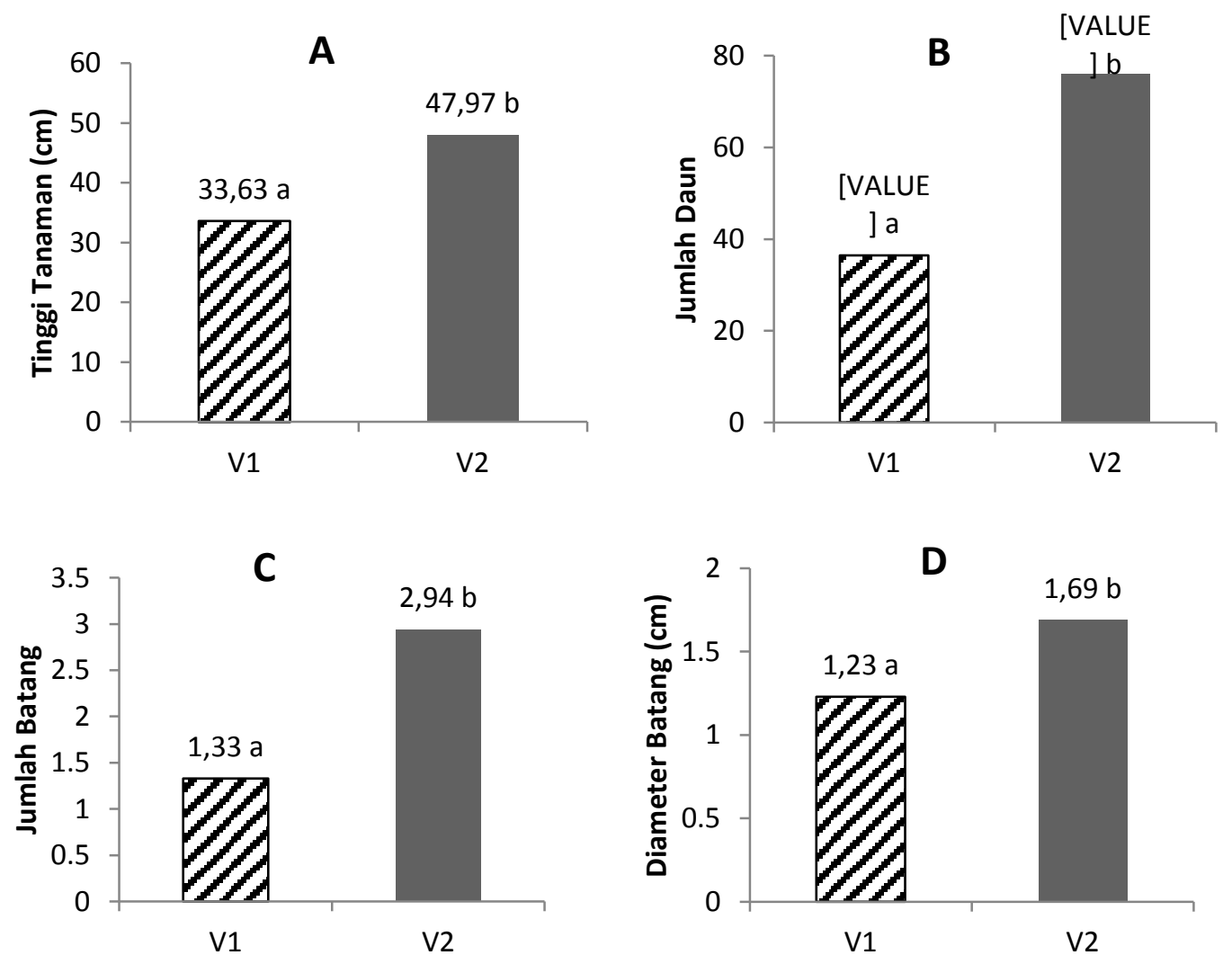

Gambar 1. Rata-rata tinggi tanaman (A), jumlah daun (B), jumlah batang $(C)$ dan diameter batang (D) dua varietas tanaman kentang pada perlakuan pemberian pupuk NPK.

Hasil analisis tanah yang dilakukan di Laboratorium Kimia Tanah Universitas Brawijaya menunjukkan bahwa kandungan Nitrogen di lokasi penelitian pada umumnya termasuk dalam kategori yang tinggi dengan nilai 0,54\%, demikian juga kandungan Fosfor termasuk dalam kategori tinggi dengan nilai 34,66 ppm dan kandungan kalium tergolong dalam kategori sedang dengan nilai 0,51 me/100g. Semakin tinggi dosis pupuk yang diberikan, maka kandungan unsur hara yang diterima oleh tanaman semakin tinggi, namun pemberian dengan dosis yang berlebihan justru dapat mengakibatkan timbulnya gejala kelayuan pada tanaman. Menurut Nasrullah (2015) mengemukakan bahwa unsur hara $\mathrm{N}$ berperan merangsang pertumbuhan 
batang, cabang dan daun tanaman serta membentuk zat hijau daun, lemak, protein dan senyawa organik lainnya. Begitu juga dengan unsur $P$ yang berperan merangsang pertumbuhan akar terutama pada benih dan tanaman yang masih muda serta unsur $\mathrm{K}$ yang berperan memerkuat batang tanaman agar tidak mudah roboh. Pemberian NPK sesuai takaran meningkatkan pertumbuhan (tinggi dan diameter tanaman) dan produksi tanaman (jumlah bunga, jumlah buah, bobot buah pertanaman) (Sutrisna dan Surdianto, 2014).

\section{Pengaruh Pemberian Dosis Pupuk N-P-K Terhadap Hasil Dua Varietas Tanaman Kentang (Solanum tuberosum L.)}

Hasil analisis ragam menunjukkan bahwa pemberian pupuk NPK memberikan pengaruh yang nyata terhadap parameter jumlah umbi Per-tanaman, bobot umbi Pertanaman dan bobot umi Per-hektar. Dari ketiga parameter tersebut yang memiliki hasil terbaik adalah perlakuan dosis pupuk NPK $400 \mathrm{~kg}$ ha-1 pada varietas Granolla Arjuno (Tabel 2).

Tabel 2 menunjukkan bahwa parameter hasil jumlah umbi Per-Tanaman, bobot segar umbi Per-Petak, dan bobot segar umbi Per-Hektar yang memiliki jumlah dan bobot yang paling tinggi yaitu terdapat pada perlakuan P1V2 (pupuk NPK $400 \mathrm{~kg}$ ha-1 dengan varietas Granolla Arjuno) dan berbeda nyata dengan perlakuan yang lainnya dengan jumlah umbi Per-Tanaman 19,00 umbi, bobot segar umbi Per-Tanaman 407,56 g, dan bobot segar umbi Per-Hektar 20,38 ton.

Tabel 2. Rata-rata jumlah umbi per-tanaman, bobot umbi segar per-tanaman dan bobot umbi segar dua varietas kentang akibat perlakuan pemerian dosis pupuk NPK $(16: 16: 16)$

\begin{tabular}{|c|c|c|c|}
\hline \multirow[b]{2}{*}{ Perlakuan } & \multicolumn{3}{|c|}{ Parameter Hasil } \\
\hline & $\begin{array}{c}\text { Jumlah Umbi Per- } \\
\text { Tanaman }\end{array}$ & $\begin{array}{c}\text { Bobot Umbi Segar Per- } \\
\text { Tanaman }(\mathrm{g})\end{array}$ & $\begin{array}{l}\text { Bobot Umbi Segar } \\
\left.\text { (ton ha } \mathrm{ha}^{-1}\right)\end{array}$ \\
\hline P0V1 & $5,33 a b$ & $127,67 \mathrm{a}$ & $6,38 \mathrm{a}$ \\
\hline P1V1 & $6,00 a b$ & $120,67 \mathrm{a}$ & $6,03 \mathrm{a}$ \\
\hline P2V1 & $5,00 \mathrm{a}$ & $135,00 \mathrm{a}$ & $6,75 \mathrm{a}$ \\
\hline P0V2 & $9,67 \mathrm{ab}$ & $301,89 \mathrm{~b}$ & $15,09 b$ \\
\hline P1V2 & $19,00 \mathrm{c}$ & $407,56 \mathrm{c}$ & $20,38 c$ \\
\hline P2V2 & $10,33 b$ & $237,97 \mathrm{~b}$ & $11,90 \mathrm{~b}$ \\
\hline BNT 5\% & 5,17 & 99,27 & 11,03 \\
\hline
\end{tabular}


Secara terpisah pemberian pupuk NPK tidak memberikan pengaruh yang nyata terhadap varibel hasil, sedangkan macam varietas memberikan perbedaan yang nyata dimana varietas Granolla Arjuno menghasilkan jumlah umbi per-petak (Gambar 2A) yang lebih banyak daripada varietas Granolla $L$ sedangkan untuk bobot segar umbi Per-Petak (Gambar 2B) Varietas Granolla L menghasilkan umbi dengan bobot yang lebih tinggi dibandingkan varietas Granolla $\mathrm{L}$.
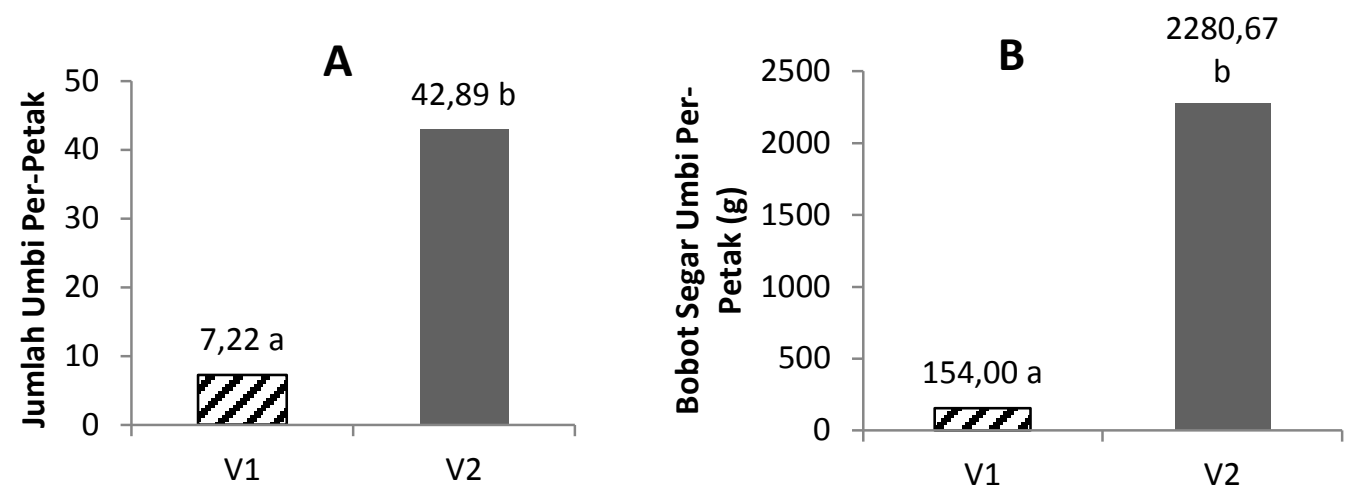

Gambar 2. Rata-rata jumlah umbi per-petak (A) dan bobot umbi per-petak (B) dua varietas tanaman kentang pada perlakuan pemberian pupuk NPK.

Perlakuan dengan dosis $400 \mathrm{~kg}$ pupuk N-P-K mutiara ha ${ }^{-1}$ dengan varietas Granolla Arjuno (P1V2) memiliki bobot segar umbi yang paling tinggi yaitu 20,38 ton $\mathrm{ha}^{-1}$ dan berbeda nyata dengan perlakuan yang lainnya. Tingginya hasil yang yang diperoleh perlakuan P1V2 kemungkinan disebabkan oleh ketersediaan unsur hara pada perlakuan P1V2 sesuai dengan kebutuhan hara tanaman pada varietas Granolla Arjuno (Tabel 2).

Pertumbuhan tanaman menjelang fase generatif cukup baik, namun pada saat pematangan umbi tanaman terkena penyakit Phytopthora infestans, maka dari itu kentang dipanen 15 hari lebih cepat dari waktu panen normal kentang varietas Granolla (115). Sesuai dengan penelitian Sutrisna dan Surdianto (2014) bahwa tanaman kentang memerlukan zat-zat makanan atau unsur hara makro N, P, K, S, Mg, $\mathrm{Ca}$ dan unsur hara mikro Mo, Cu, B, Zn, Fe, dan Mn. Unsur hara yang sangat mempengaruhi produktivitas kentang ialah unsur $\mathrm{P}$ dan $\mathrm{K}$. Unsur hara tersebut diperoleh dari dalam tanah (tersedia) dan melalui pemupukan. NPK merupakan salah satu upaya penambahan unsur hara makro NPK ke dalam tanah dengan harapan unsur hara lainnya sudah tersedia di dalam tanah. Dengan demikian unsur hara P dan 
K yang tinggi kandungannya pada pupuk majemuk NPK lebih baik untuk tanaman kentang di lahan dataran tinggi seperti wilayah Batu.

Keseimbangan unsur hara terutama $\mathrm{K}$ di dalam tanah sangat berperan dalam sintesis karbohidrat dan protein. Kalium terlibat dalam mengaktifkan enzim yang berperan dalam proses metabolisme karbohidrat, lemak dan Protein. Ada banyak faktor yang berpengaruh terhadap pembentukan umbi pada kentang diantaranya: intensitas cahaya, kualitas cahaya, dan lamanya waktu penyinaran yang diterima oleh daun (Parman, 2010).

\section{Kesimpulan dan Saran}

Berdasarkan hasil penelitian dapat disimpulkan bahwa perbedaan dosis pupuk $\mathrm{N}-\mathrm{P}-\mathrm{K}$ secara umum tidak berpengaruh signifikan terhadap pertumbuhan dan hasil dua varietas kentang, namun pemberian $400 \mathrm{~kg}$ pupuk NPK ha-1 pada varietas Granolla Arjuna (P1V2) memberikan pertumbuhan dan hasil yang terbaik. Hasil penelitian ini menyatakan bahwa Varietas Granolla Arjuno memiliki pertumbuhan dan hasil umbi yang secara nyata lebih baik dibandingkan dengan varietas Granolla L.

\section{Daftar Pustaka}

Ariana, E. 2009. Uji Pupuk NPK Mutiara 16:16:16 dan berbagai jenis mulsa terhadap hasil tanaman cabai (Capsicum annum L.). Jurusan Budidaya Pertanian Fakultas Pertanian Universitas Riau. Jurnal Sagu, 8(1):5-8.

Gunadi, N. 2009. Pengaruh sumber dan dosis pupuk kalium terhadap pertumbuhan dan hasil kentang. Prosiding Seminar Nasional Pekan Kentang 2008, hal. 13450.

Kementerian Pertanian Republik Indonesia. 2019. Data Lima Tahun Terakhir (20142018). $\quad$ https://www.pertanian.go.id/home/?show=page\&act=view\&id=61. Diakses 20 Januari 2019.

Nasrullah, Nurhayati, A. Marliah. 2015. Pengaruh dosis pupuk NPK (16:16:16) dan mikoriza terhadap pertumbuhan bibit Kakao (Therobrama cacao L.) pada media tumbuh subsoil. J. Agrium. 12(2):56-64.

Nurhidayati, 2017. Kesuburan dan kesehatan tanah : suatu pengantar penilaian kualitas tanah untuk sitem pertanian yang berkelanjutan. Intimedia Malang. Hal 285 .

Nurtika, N., E. Sofiari, G.A. Sopha. 2008. Pengaruh biokultur dan pupuk anorganik terhadap pertumbuhan dan hasil kentang varietas granola. J. Hort. 18(3):267277.

Parman, S. 2010. Pengaruh intensitas cahaya terhadap produksi umbi tanaman lobak (Raphanus Sativus L). Buletin Anatomi Dan Fisiologi. 18(2): 29-38.

Qomariyah, N. 2018. Uji daya pertumbuhan dan hasil beberapa genotip kentang (Solanum tuberosum L.) di dataran medium. Skripsi. Fakultas Pertanian UNISMA. Malang.

Rahayu. 2000. Pengaruh penggunaan pupuk nitrogen dan fosfat terhadap mutu umbi kentang. Bul. Penel. Hort. XV (1) :72-8.

Sutrisna, N., Y. Surdianto. 2014. Kajian formula pupuk NPK pada pertanaman kentang lahan dataran tinggi di Lembang Jawa Barat. J.Hort. 24(2): 124-132. 